\title{
Assessment of Chemical, Physical, and Safety Hazards in
}

\section{Paper Industry in Dammam}

\author{
Khaled F. El-Said
}

\begin{abstract}
Paper and pulp industry represent a major industrial sector in Saudi Arabia. Workers in the paper industry may be exposed to a variety of chemicals, chlorinated organic compounds carbon monoxide $(\mathrm{CO})$, nitrogen dioxide $\left(\mathrm{NO}_{2}\right)$, sulfur dioxide $\left(\mathrm{SO}_{2}\right)$, benzene, methane, and a variety of physical hazards such as noise, heat, and illumination. The present study aimed at assessing the occupational chemical, physical, and safety hazards in different departments of paper industry, and administrative area. Levels of noise, heat, and illumination were measured using a standardized technique. Chemical exposure was assessed by measuring different pollutants as $\mathrm{SO}_{2}$, $\mathrm{CO}$, Methane, and Benzene. safety measures were conducted in different paper plant. Analyzed data revealed high significant differences in the level of noise and heat between exposed and controlled area. However, there are no significant differences between the levels of illumination. Nevertheless, there are high significant differences in the levels of measured chemicals in paper plant departments in comparison with administrative area. These observations clearly support the need for further research on the effect of occupational exposure to chemicals and physical agents on workers in paper industry.
\end{abstract}

\section{INTRODUCTION}

During the last decades and owing to the industrial development, chemical substances in the work environment have substantially increased. They are potentially toxic and many of them have adverse effects on workers health. Nevertheless, exposure to chemical as well as physical agents in the paper industry are associated with various health outcomes such as lung injuries and eventually mortality and morbidity.(1) Occupational exposure and epidemiological studies showed that inhalation of dust (paper and soft-paper) and chlorine compounds seriously affect lung function, exacerbate allergic asthma, and reactive airways dysfunction syndrome. Paper industry workers are

${ }^{*}$ Assistant Professor of Occupational Hygiene, Occupational Health Department, High Institute of Public Health. Alexandria University, Egypt. 
exposed to a mixture of irritant gases and dust including organic solvents, minerals, and heavy metals. ${ }^{(2)}$

In recycling paper industry a mixture of used newspapers, magazines, and waste from the production of corrugated paper was repulped without deinking. The paper was mixed with water in the pulper, major impurities such as staples were removed, the recycled paper was refined, and sizing agents, chemicals, fillers, and other chemicals were added to the recycled paper stock. ${ }^{(2)}$

In the paper industry, excess of physical, chemical, and safety hazards were found in the pulping and refining departments and on-machine coating and winding of paper/paperboard. Exposures to asbestos, carbon monoxide, formaldehyde, fungal spores, bacteria, nitrogen dioxide, minerals dusts, paper dust, sulphuric acid, and different solvents sometimes exceeded exposure limit values. ${ }^{(3,4)}$

Workers in the pulp industry may be exposed to a variety of chemicals, chlorinated organic compounds, carbon monoxide, nitrogen dioxide, sulfur dioxide, benzene, methane, polychlorinated dibenzodioxins, and dibenzofurans have been found in paper industry. ${ }^{(4)}$

Exposure to heat, pressure, and reactive chemicals during paper production results in the formation/emissions of inorganic and organic byproducts that can pose significant threat to employees' health.(3) High environmental temperatures and humidities appear primary in paper industries (NIOSH, 1986). ${ }^{(5)}$ Exposure to physical hazards as noise, heat, and illumination were made in areas typically considered hot environments in paper industry: the paper machines, coaters, and driers. ${ }^{(6-8)}$

Nevetheless, paper industry workers are expected to present high level of exposure to noise in different paper production departments. Moreover, lighting is one of the most important environmental 
aspects to people. Lighting of industrial areas covers a multitude of different visual tasks, requiring different lighting solution and different lighting equipment. ${ }^{(9)}$

Some of the safety considerations in industry include: structure safety, fire safety, health safety, special emergencies, accident prevention, ,..,etc. In the present study, the collected data will cover the different occupational health and safety aspects including: the basic information of safety measures, layout, and arrangement, ventilation, illumination, equipment, housekeeping and maintenance, fire safety, disposal of hazardous wastes, safety equipment, and safety practices. ${ }^{(2,5)}$ The goal of this study was to assess physical, chemicals, and safety hazards in different departments of paper industry.

\section{MATERIAL and METHODS}

The present study was conducted in the paper and pulp plant located in the second industrial area in Dammam, Saudi Arabia. Measurements of physical and chemicals hazards were conducted inside different departments of the paper plant as storage area, raw material, pulping, screen area, paper machine (coating, drying, and rolling), final product storage, boiler department, and finally in workshop area. and in administrative building.

Physical hazards as heat stress, noise, and illumination were assessed using WBGT index (GENEQ), sound level meter ( TES 1352A), and Lux meter (TES 1336A), respectively ${ }^{(10)}$. Moreover, the Level of gaseous emissions as sulfur dioxide, Carbon Monoxide, Methane, and Benzene inside paper and pulp plants were measured using MIRAN (Thermo 205B-X L1A3N). ${ }^{(11)}$

A pre-designed questionnaire was used for safety measure data collection and evaluate fire hazards, electrical hazards, ventilation system, Personal protective equipment (PPE), and housekeeping,...,etc., in different departments of paper plant departments. 


\section{Statistical Analysis}

Statistical analysis was performed by using SPSS software. Student " $t$ test" was used for comparison of the means. Statistical significance was considered for $P$ values less than 0.05 and 0.01 .

\section{RESULTS} Table 1 shows the mean levels of administrative area. noise, heat, and illumination measured in paper plant departments and administrative area, where there are high significant differences in the level of noise and heat stress $p<0.01$. However, there are no significant differences in the level of illumination in paper plant departments and

Table 1: Comparison of Mean levels of physical hazards in paper industry and administrative departments

\begin{tabular}{|lllc|}
\hline & $\begin{array}{l}\text { Paper plant departments } \\
\text { Mean } \pm \text { SD }\end{array}$ & $\begin{array}{l}\text { Administrative Area } \\
\text { Mean } \pm \text { SD }\end{array}$ & $\mathrm{t}$-Value \\
\hline Noise (dB) & $82.21 \pm 9.04$ & $59.67 \pm 2.48$ & $7.45^{\star *}$ \\
\hline $\begin{array}{l}\text { Heat Stress } \\
\text { (WBGT) }\end{array}$ & $26.23 \pm 1.08$ & $20.8 \pm 7.48$ & $11.2^{\star *}$ \\
\hline $\begin{array}{l}\text { Illumination } \\
\text { (Lux) }\end{array}$ & $333.10 \pm 27.3$ & $443.9 \pm 18.17$ & 1.55 \\
\hline${ }^{* *} \mathrm{P}<0.01$ & & \\
\hline
\end{tabular}




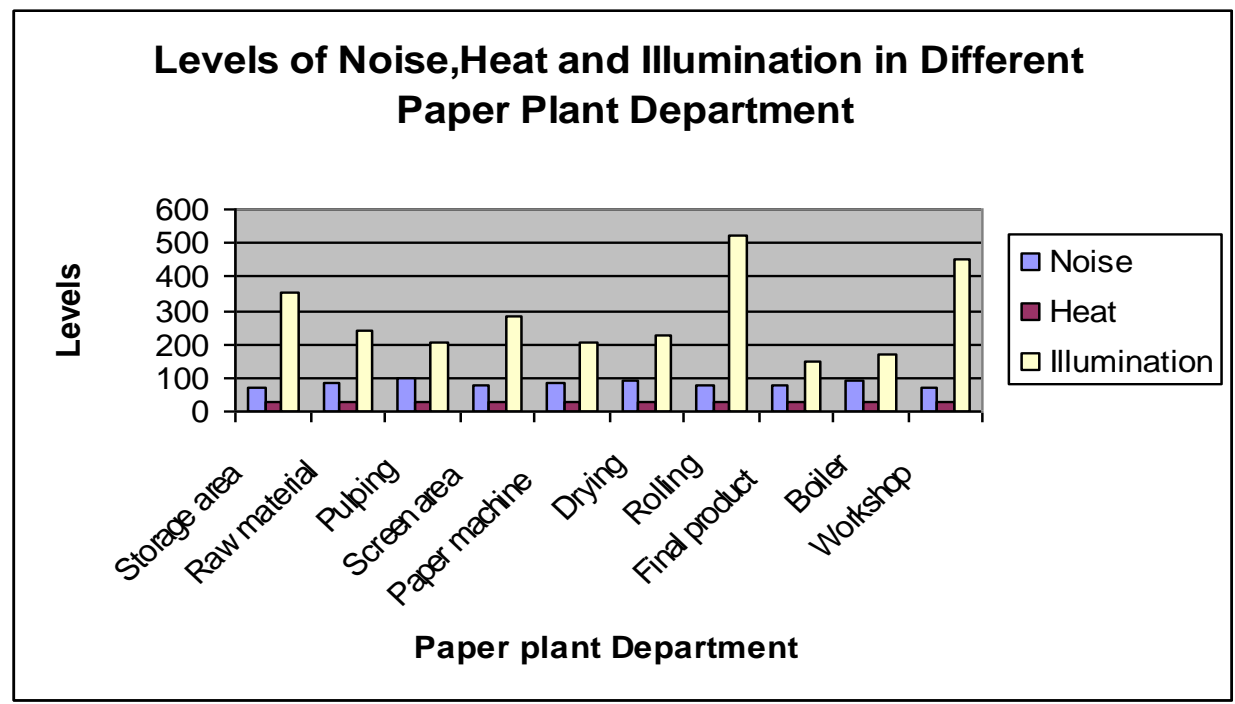

Figure 1.Levels of Physical hazards in Paper plant Departments

Figure (1) shows levels of noise, heat, and illumination in paper plant departments where highest level of illumination was found in storage area and the lowest level in final product. High level of noise was found in pulping department, while lowest noise was in storage area. lowest heat exposure was found in storage area and highest level of heat exposure was in the drying department.
Mean levels of measured gases as sulphur dioxide, carbon monoxide. Benzene, and methane in paper plant departments and administrative area are presented in Table 2, where there is high significant difference in the level of carbon monoxide $(p<0.01)$ and in levels of sulphur dioxide, benzene, and methane $(p<0.05)$ in paper plant departments in comparison with administrative area. 
Table 2: Comparison of Mean Levels of Chemical Hazards in paper industry and administrative departments

\begin{tabular}{|lccc|}
\hline & $\begin{array}{c}\text { Paper plant departments } \\
\text { Mean } \pm \text { SD }\end{array}$ & $\begin{array}{c}\text { Administrative Area } \\
\text { Mean } \pm \text { SD }\end{array}$ & t -Value \\
\hline Sulphur dioxide & $12.48 \pm 9.61$ & $2.66 \pm 0.016$ & $3.16^{*}$ \\
\hline Carbon Monoxide & $6.556 \pm 3.45$ & $3.833 \pm 4.79$ & $4.60^{\star *}$ \\
\hline Benzene & $11.883 \pm 9.07$ & $0.263 \pm 0.040$ & $3.10^{*}$ \\
\hline Methane & $21.15 \pm 15.84$ & $0.25 \pm 0.614$ & $3.24^{*}$ \\
\hline
\end{tabular}

$$
{ }^{\star} \mathrm{P}<0.05 \quad{ }^{* *} \mathrm{P}<0.01
$$

Figure 2 shows different levels of of lowest sulpher dioxide gas was found in measured gases in paper plant rolling department . Lowest level of carbon departments where, highest level of monoxide, benzene, and methane gas measured gases were found in drying were found in raw material and pulping department of the paper plant and the area, respectively.

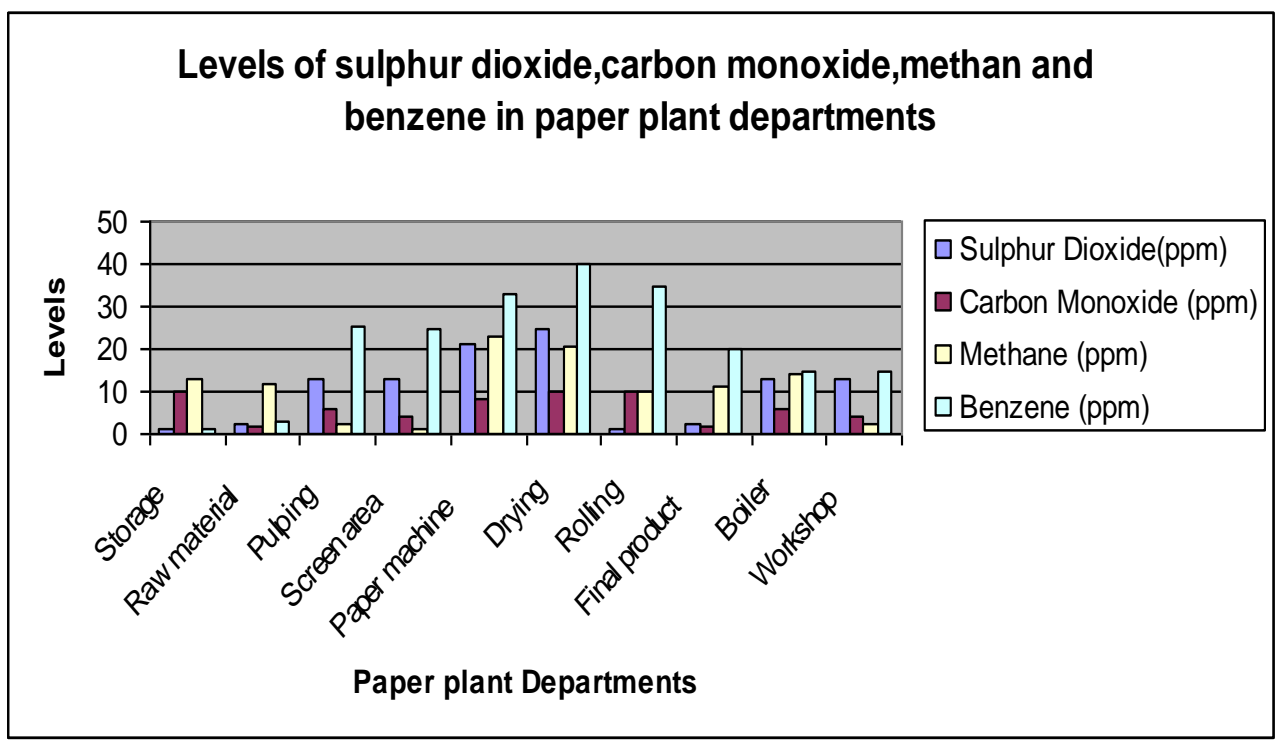

Figure2. Levels of Measured Gases in Paper plant Departments 
Table 3.Safety hazards assessment in different sector in paper industry

\begin{tabular}{|l|c|c|}
\hline Safety Measures & Adequate & Poor \\
\hline Ventilation & 16.7 & 83.3 \\
\hline First aid & 66.7 & 33.3 \\
\hline Safety Signs & 5 & 95 \\
\hline Housekeeping & 66.7 & 33.3 \\
\hline Spill & 33.3 & 66.7 \\
\hline PPE & 90 & 10 \\
\hline Ergonomics & 33.3 & 66.7 \\
\hline Fire extinguisher & 16.7 & 83.3 \\
\hline Accident Records & 5 & 95 \\
\hline Medical Records & 10 & 90 \\
\hline Safety Inspection & 20 & 80 \\
\hline Emergency & 83.3 & 16.7 \\
\hline Safety Training & 50 & 50 \\
\hline Safe Guard & 83.3 & 16.7 \\
\hline Lay out & 66.7 & 33.3 \\
\hline Ambulance Services & 15 & 85 \\
\hline Hazard awareness & 66.7 & 33.3 \\
\hline
\end{tabular}

The evaluations of the safety factors in the surveyed industry are presented in Tables 3 and Figure 3 , The evaluation of the chosen factors (adequate and poor) was based on check lists which were assessed mainly subjectively, ventilation, first aid, safety signs, housekeeping ,spill, personal protective equipment, ergonomics hazards, fire extinguisher, accident record, medical records, inspection emergency training, safe guard, lay out, ambulance, and hazard awareness.

The conditions of many of the safety criteria are not satisfactory as ventilation, first aid housekeeping, spill, personal protective equipment, ergonomics hazards, layout, and hazard awareness. However, the other conditions are satisfactory and adequate. 


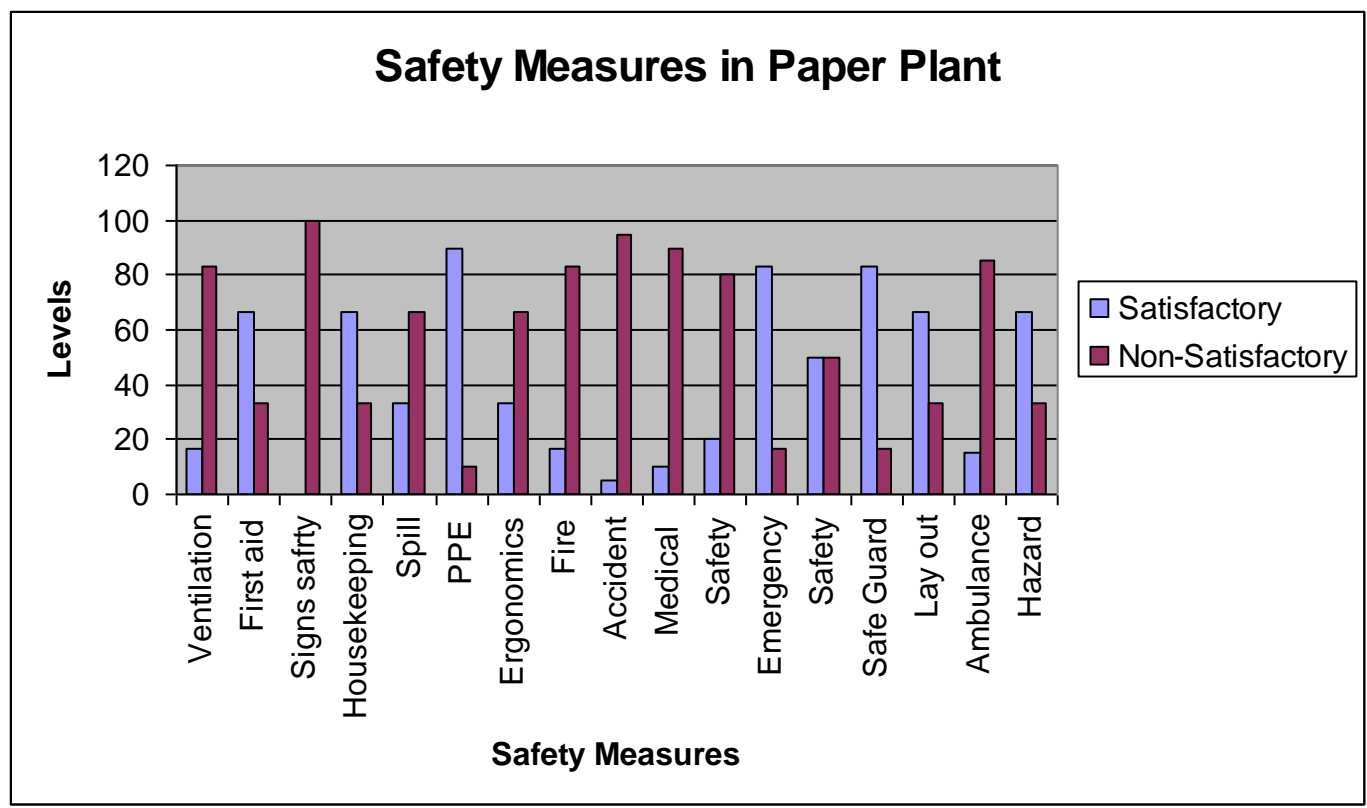

Figure 3. Safety Measures in Paper Plant Departments

\section{DISCUSSION}

Workers in paper industry may be exposed to a variety of physical hazard such as noise, heat, light, vibration, and radiation.

Our results have shown that the levels of noise in the paper industry plants under study exceeds both TLW-TWA (8-h shift) of $85 \mathrm{~dB}$, and action level as they are defined by the Saudi Arabia legislation. and these findings are in accordance with recent studies which revealed that Exposure to loud noise may cause temporary or permanent damage to the peripheral auditory organ. ${ }^{(12)}$

The present study shows significant high levels of the occupational exposure to heat (WBGT) where there is highly significant differences between paper plant departments and administrative area. $(p=$ 
0.01). Our results have shown that the level of heat in paper industry reachss an average of $30^{\circ} \mathrm{C}$ which exceeds the OSHA standard level of $28^{\circ} \mathrm{C}$ which in turn can cause serious health effects as heat stress, heat rash, heat cramps, and heat stroke. These findings are in accordance with recent studies $(8,13)$

Concerning illumination levels, our results show no-significant levels of illumination in paper plant departments and administrative area but the illumination level in many industrial operation is still below the recommended level (TLV). ${ }^{(7)}$

Occupational exposure to some chemicals may cause serious occupational diseases and injuries $n$ workers engaged in industrial sectors in paper industry. Paper industry workers are exposed to respiratory irritants, such as sulfur dioxide, hydrogen sulfide, and chlorine compounds. ${ }^{(14-16)}$

Concerning exposure to chemical pollutant in paper and pulp industry, the levels of $\mathrm{SO}_{2}, \mathrm{CO}$, methane, and benzene were significantly higher in paper plant departments in comparison with its levels in administrative area. These findings clarify the prevalence of different respiratory, skin, and neurological diseases among paper industry and our results are in accordance with different recent studies dealing with effect of exposure to chemical pollutants in workers in paper industry. ${ }^{(16-18)}$ In the present study in old and new paper and pulp industry the mean measured levels of $\mathrm{SO}_{2}$ were $12.48 \mathrm{ppm}$ which exceeds the TLV recommended limit of 5 ppm. ${ }^{(16-18)}$ However, measured mean level of CO were $6.5 \mathrm{ppm}$ which was still under the TLV limits of 35ppm. ${ }^{(7)}$

For Benzene the mean level of 21.0 ppm which highly exceeds the TLV recommended limits of 1 ppm..$^{(7,16-20)}$ and might due to uses of multi-types of organic solvents inside industry especially in pulping sectors and these findings are in accordance with recent studies which 
revealed that mean personal exposures to benzene ranging from 4 to $18 \mu \mathrm{g} / \mathrm{m}^{3} . \mathrm{In}$ contrast, the level of exposures reported for outdoor workers in the few studies undertaken in developing countries is generally higher, with benzene ranging from 20 to $204 \mu \mathrm{g} / \mathrm{m}^{3}$. $^{(17-21)}$

However, mean measured level of methane was 11.8 ppm which represents high level of methane exposures and it is a primary cause of asphyxiation among paper and pulp workers where there is no published TLV for methane.(17-21)

Occupational heath and safety assessment is concerned with implementation of prospective plan for the protection of the work environment. In the present study the conditions of many of the safety criteria are not satisfactory as ventilation, first aid housekeeping, spill, personal protective equipment, ergonomics hazards, lay out and hazard awareness. However, the other conditions are satisfactory and adequate.

\section{CONCLUSION}

In conclusion, this study has shown a high risk of exposed workers from exposure to different physical, chemical, and safety hazards in paper industry. There are several preventable risk factors, so such industry needs education and training concerning safety performance to reduce prevalence of occupational accidents. These observations clearly support the need for further research on the effect of occupational exposure to chemicals and physical agents on workers in paper industry.

Acknowledgements: The authors thank Abddulmalik S. Al-Saif and Khaled M. AlOtabi, graduate students from College of Applied Medical Sciences, King Faisal University, who provided support in the paper factory.

\section{REFERENCES}

1- Ballal SG, Ahmed HO, Sebiany AM. Occupational health in Saudi Arabia: Occup Med. 2002;17(3):491-507.

2- OSHA. Inspection narrative for OSHA inspection No. 100987551, Champion 
International Paper Company. U.S. Department of Labor, Occupational Safety and Health Administration, Augusta Area Office. Memorandum for Regional Administrator, February 12, 1991.

3- Chalbot MC, Vei I, Lykoudis S, Kavouras IG. Particulate polycyclic aromatic hydrocarbons and n-alkanes in recycled paper processing operations. J Hazard Mater. 2006; 137(2):742-51.

4- Korhonen $\mathrm{K}$, Liukkonen $\mathrm{T}$, Ahrens $\mathrm{W}$, Astrakianakis G, Boffetta P, Burdorf A, et al. Occupational exposure to chemical agents in the paper industry. Int Arch Occup Environ Health. 2004;77(7):451-60.

5- NIOSH. Criteria for a recommended standard: occupational exposure to hot environments, revised criteria. Cincinnati, OH: U.S: Department of Health and Human Services, Public Health Service, Centers for Disease Control, National Institute for Occupational Safety and Health; DHHS (NIOSH) Publication No. 86113. 2004.

6- Mill ,H. Occupational environment of paper mill workers in South India. Ann Occup Hyg. 2000 :22: 371-82.

7- ACGIH TLV, BEL S. Threshold limit values for chemical substances and physical agents and biological exposure indices, 168-76, Cincinnati ACGIH Signature Publications,. 2004

8- Yoram Epstein, MORAN DS. Thermal Comfort and the Heat Stress Indices Industrial Health. 2006; 44: 388-98

9- IES: American National Standard Practice for Industrial Lighting [RP7] illumination Engineering Society, New York, N.Y: 1991.

10- www.tes.com

11- Thermo Electron Corporation Environmental Instruments. MIRAN 205B Series Sapphlre Portable
Ambient Air Analyzer. Instruction Manual, P/N BK3538, USA. 2004. www.thermo.com/eid.

12- National Institute for Occupational Safety and Health (NIOSH). Proposed national strategy for the prevention of noise-induced hearing loss. Cincinnati $(\mathrm{OH})$ : NIOSH; 1998. DHHS publication no 89-135. p. 51-63.

13- National Institute for Occupational Safety and Health (NIOSH). Criteria for a Recommended Standard Occupational Exposure to $\mathrm{Hot}$ Environments, Revised 1986. USDHEW(NIOSH). 1986. Pub. No. 86113.

14- Henneberger PK, Olin AC, Andersson E, Hagberg S, Torén K. The incidence of respiratory symptoms and diseases among pulp mill workers with peak exposures to ozone and other irritant gases.Chest. 2005 Oct;128(4):302837.

15- Sivo D, Bisceglia L, de Nichilo G, Bruno S, Assennato G. Mortality among workers employed in the production of pulp and paper in Apulia G Ital Med Lav Ergon. 2003;25 Suppl(3):24-5.

16- Glindmeyer HW, Lefante JJ, Freyder LM, Friedman $M$, Weill $H$, Jones RN.Relationship of asthma to irritant gas exposures in pulp and paper mills. Respir Med. 2003;97(5):541-8.

17- Anonymous. Long-term effects of sulfur dioxide exposure in pulp mills. $\mathrm{Br} \mathrm{J}$ Ind Med. 2000.21:69-73.

18- Laakkonen A, Kyyrönen P, Kauppinen T, Pukkala El. Occupational exposure to eight organic dusts and respiratory cancer among Finns. Occup Environ Med. 2006;63;726-33

19- Tovalin $H$, Valverde $M$, Morandi $M$, Whitehead L, Rojas E. DNA damage in outdoor workers occupationally exposed to environmental air 
pollutants. Occup Environ Med. 2006;63:230-6.

21- Goyer N, Lavoie J.Emissions of chemical compounds and bioaerosols during the secondary treatment of paper mill effluents. AlHAJ. 2001;62(3):330-41. Andersson E, Torén K, Wingren G, et al. Cardiovascular mortality among Swedish pulp and paper mill workers. Am J Ind Med. 2007 ;50(3):221-6. 